\title{
Effects of Four Solanum melongena L. Varieties on some Haematological Indices and Weight of Organs in Albino Rats
}

\author{
*Ossamulu, I.F., Akanya, H.O., Egwim, E.C., Adeyemi, H.Y., Isa, U.L., and \\ Tsado, A.N \\ Department of Biochemistry, School of Natural and Applied Science, Federal University of Technology, P.M.B \\ 65, Minna, Niger State, Nigeria.
}

\begin{abstract}
The effects of four eggplant varieties on haematological indices and weight of organs in albino rats were evaluated. A total of 108 albino rats were randomly distributed into two major blocks of treatments $(10 \%$ and $20 \%$ supplenentations), each having four sub groups with 12 rats each. The sub groups were based on the eggplant variety used in supplementation. Rats in groups $A, B, C$ and $D$ were fed diet supplemented $S$. Macrocapron (round), S. atheopicum, S. Macrocapron (oval), and S. gilo respectively. A general control group labelled 'control' was fed with commercial rat feed. Three rats from each group were sacrificed weekly and their kidney, liver and heart weighed. The haematological indices were determined using an automated haemacytometer machine. The liver, kidney and heart weight to body weight were not significantly different $(p>0.05)$ from the control within and between treatments. The white blood cell count of rats placed on $10 \%$ eggplant supplemented diet ranged from $4.51 \pm 0.20 \times 10^{3} / \mu \mathrm{L}$ to $5.43 \pm 0.10 \times 10^{3} \mathrm{ml} / \mu \mathrm{L}$ while rats supplemented with $20 \%$ eggplant were within $4.74 \pm 0.13 \times 10^{3} / \mu \mathrm{L}$ and $5.56 \pm 0.10 \times 10^{3} / \mu \mathrm{L}$. There was a significant increase in the white blood cell count of rats placed on the eggplant supplementations except group C (S. macrocarpon (oval)). The red blood cell count was significantly lower in all the groups compared to the control except in rats placed on $10 \% \mathrm{~S}$. Marcrocapon (round) supplemented diet. The result has shown that eggplant varieties significantly reduced $R B C$, increased the WBC count was increased with no significant change in PCV.
\end{abstract}

Key Words: Packed cell volume, red blood cell, white blood cell, Eggplant.

\section{Introduction}

Haematological parameters are linked with health status and are important in the clinical evaluation of the state of health (Saliu, Elekofehinti, Komolafe and Oboh, 2012). It is known that some acute and chronic diseases adversely affect blood cells; this therefore makes the analysis of blood parameters very relevant in estimating alterations in human haematological system (Olson et al., 2000). Fruit and vegetable consumption have been shown by wide epidemiological studies to reduce the risk diseases such as cancer, heart disease and stroke (Block et al., 1992) among others. A diet rich in fruits and vegetables has recently been found to positively affect serum antioxidant capacity and protect against lipid peroxidation. Free radicals may cause disruption of membrane fluidity, protein denaturation, lipid peroxidation and alteration of platelet functions, which may be associated with many chronic health problems. Fruits are very important for health optimisation (Ibrahim, 2011) as such inadequate intake may increases the risk of illness and several haematological disorders from contagious diseases because of lowered defence system which in turn compromise the normal body physiology (Black, 2003). Recent research has shown that a wide range of indigenous fruit trees have the potential to provide rural households with a means to meet their nutritional and medicinal needs (Ekesa et al., 2009).

Among these fruits is eggplant (Solanum melongena $\mathrm{L}$ ) which is a member of the night shade family. It is believed to have originated from tropical Africa (Grubben and Denton, 2004) and belongs to the subgenous leptostemanum melongena (Obeng-Ofori et al., 2004). This fruit is famous in india and commonly referred to as brinjal (Kantharajah and Golegaonkar, 2004). In Nigeria, the Hausa's call it Gauta/yalo; Igbo: afufa or añara, Nupe: yengi and Yoruba: igbagba (Ossamulu et al., 2014). The Gilo, Kumba, Shum and Aculeatum are four cultivar groups recognized within solanum species of which the first three are most important in Africa (Horna and Gruere, 2006). Solanum melongena possess various nutritional and medicinal values that make them valuable addition to diets. This is basically because they have appreciable reserve of nutrients and loads of phytochemical compounds. They are rich in many mineral elements such as calcium, phosphorus, iron, sodium and potassium. Eggplants also contain phenol antioxidants (flavonoids, monophenols and polyphenols) which are partly responsible for their beneficial effects on heart disease, cancer (Vinson et al., 2005; Stover et al., 2007) amongst other ailments.

Solanum melongena fruit is helpful in preventing and treatment of several diseased conditions as it is effective in the reduction of blood cholesterol levels (Ossamulu et al., 2014b), in regulating high blood 
pressure, in weight reduction and it possess anti-glaucoma effects. In traditional Chinese medicine, all parts of the plant can be used to stop intestinal bleeding. The fruit is used as an antidote in cases of mushroom poisoning. In malay medicine, the ashes are used in dry, hot poultice to treat haemorrhoids. Other medicinal applications include the use of the roots and fruits as carminative and sedatives, and to treat coelic problems (Ibiam and Nwigwe, 2013). The leaf juice is used to treat uterine complaints, and alcoholic extract of leaves as a sedative, anti-emetic and to treat tetanus after abortion (Doganlar, Frary, Daunay, Lester and Tanksley, 2002).

\section{Plant Material}

\section{Materials and Methods}

The different Eggplants cultivars used were obtained from a farmland in kudenda Kaduna, Nigeria. The samples were transported to the laboratory and were identified by a taxonomist in the department of Biological Science, Federal University of Technology Minna Niger State, Nigeria. The samples were dried at room temperature, pulverised and stored in containers for further use.

\section{Experimental Animals}

Young adult albino rats weighing between $110 \mathrm{~g}-130 \mathrm{~g}$ were used for this study. The rats were obtained from a private farm (Ijeoma Rodent Farms) in Zaria, Kaduna state, Nigeria and transported to the research site (Biochemistry department, Federal University of Technology Minna Niger State, Nigeria).

\section{Management of Experimental Animals}

The animals were allowed to acclimatize for 2 weeks under standard laboratory conditions. They were maintained on standard rat feed and potable water ad libitum. They were handled in strict compliance with international guidelines as prescribed by the Canadian Council on the Care and Use of Laboratory Animals in Biomedical Research (1984).

\section{Feed Preparation}

The four eggplant samples (S. Macrocapron (round), S. Atheopicum, S. Macrocapron (oval), and $S$. gilo,) were separately supplemented into standard commercial feed at two different concentrations. The first had $10 \mathrm{~g}$ of the eggplant sample(s) mixed with $90 \mathrm{~g}$ of standard feed while the second was prepared by thoroughly mixing $20 \mathrm{~g}$ of the eggplant sample(s) with $80 \mathrm{~g}$ of commercial feed and made into pellets.

\section{Experimental Design}

A total of 108 adult Swiss albino rats were used for this study which lasted for 4 weeks (0ne month). They were randomly distributed into two major blocks of treatments (10\% and $20 \%$ eggplant supplementation) with each having four sub groups (Groups A-D) based on the eggplant cultivar. Each sub group had a total of 12 rats. Rats in group A were fed with diet supplemented with 'S. Macrocapron (round), eggplant. Similarly, rats in groups B, C and D were fed with diets supplemented with S. atheopicum, S. Macrocapron (oval), and S. gilo respectively. A general control group labelled 'control' was fed with normal commercial chow. The rats were allowed food and water freely throughout the experimental period. The rats were allowed four days adaptation period with the various supplemented diets before the commencement of the analysis. During the study, the weight gain by each rat was recorded at the end of every week. Consequently, three rats from each group were fasted for about 12 hours and sacrificed under chloroform anaesthesia. Their blood samples and organs (Liver, kidney and heart) were collected for further analysis.

\section{Blood Sample Collection}

While under chloroform anaesthesia, blood was collected from each rat via heart puncture and transferred into EDTA bottle. The collected blood samples were used for determination of Packed Cell Volume (PCV), Red Blood Cell (RBC) count and white blood cell (WBC).

\section{Determination of Red blood cell and White Blood Cell counts}

The rat blood collected in an anticoagulant bottle was used in the determination of red blood cell and white blood cell counts using the haemocytometer machine (XFA 6000 Inteligent Auto Hematology Analyzer).

\section{Determination of Packed Cell Volume (PCV)}

The blood sample collected was introduced into the capillary tubes using the syringe. The tubes were then sealed by blue flames from spirit lamp. The sealed capillary tubes were then spun in microhaematocrit centrifuged for 30 minutes at $5 \mathrm{~g}$. The respective PCVs were then read from Microhaematocrit reader (Zuckerman, 2007). 


\section{Body Weight Changes and Weight of some Visceral Organs}

The body weights and weight of the organs were obtained using a weighing balance and mean was calculated consequently, the organs to body weight ratio was calculated.

\section{Statistical Analysis}

The results were evaluated using analysis of variance (ANOVA) and were presented as the mean value \pm SEM (standard error of mean) for the control and experimental rats. Differences among the means for the groups were assessed using the Duncan's Multiple Range Test to determine which mean values were significantly different at $\mathrm{p}<0.05$ (Sokal and Rohlf, 1969).

\section{Results}

The mean organ-body weight ratio at the end of the experimental period is shown in Table 1. Rats placed on diets supplemented with $10 \%$ Solanum macrocarpon (round) had the highest kidney organ weight ratio $\left(8.31 \pm 0.17 \times 10^{3}\right)$ while $10 \% \mathrm{~S}$. gilo supplemented diets had the lowest value $\left(7.40 \pm 0.30 \times 10^{3}\right)$ although there was no significant difference ( $p>0.05)$ in the kidney/body weight ratio between rats in the control group and those in the experimental groups. The heart/body weight ratio ranged from $3.82 \pm 0.24 \times 10^{-3}$ for rats fed $20 \%$ S. aetheopicum supplemented diets to $4.45 \pm 0.37 \times 10^{-3}$ for rat placed on $10 \%$ Solanum macrocarpon (round). There was no significant difference $(\mathrm{p}>0.05)$ in the heart/body weight ratio between the control group and the experimental groups. The liver/body weight ratio was within the range of $40.04 \pm 2.71 \times 10^{-2}$ to $46.42 \pm 2.37 \times 10^{-3}$ for rats fed with $10 \%$ S. aetheopicum and $10 \%$ S.gilo supplemented diets respectively, similarly, there was no significant difference $(\mathrm{p}>0.05)$ in the liver/body weight ratio between the experimental and control groups.

The white blood cell (WBC) count of rats placed on S. aetheopicum supplemented diet had the highest concentration of $5.43 \pm 0.10 \times 10^{3} \mathrm{ml} / \mu \mathrm{L}$ for $10 \%$ formulation and $5.56 \pm 0.10 \times 10^{3} / \mu \mathrm{L}$ for $20 \%$ formulation. The white blood cell count of rats placed on the eggplant varieties except S. Macrocapon (oval) supplemented diet were significantly $(\mathrm{p}<0.05)$ higher than those in the control $\left(4.75 \pm 0.14 \times 10^{3} / \mu \mathrm{L}\right)$. There was no significant difference $(p<0.05)$ in the white blood cell count between the rats fed with $10 \%$ and $20 \%$ S. melongena varieties supplemented diets (Fig 1). Rats fed with Solanum macrocarpon (round) supplemented diet had the highest mean red blood cell count (For both $10 \%$ and $20 \%$ supplementations). The control group had a mean red blood cell (RBC) count of $7.89 \pm 0.13 \times 10^{9} / \mu \mathrm{L}$. The least red blood cell count; $6.57 \pm 0.13 \times 10^{9} / \mu \mathrm{L}$ and $6.18 \pm 0.13$ $\mathrm{x} 10 \% / \mu \mathrm{L}$ for $10 \%$ and $20 \%$ supplementations respectively were in obtained in the group placed on $S$. marcrocarpon (oval) supplemented diets. The red blood cell count was significantly lower in all the groups (both 10\% and 20\% treatments) compared to the control group (Figure 2).

Figure 3 shows the mean packed cell volume of the rats fed different eggplant supplementation. The least mean packed cell volume in $10 \%$ treatment $(40.50 \pm 0.65 \%)$ was observed in rats placed on $10 \% \mathrm{~S}$. gilo supplemented diets while $42.75 \pm 1.65 \%$ was least in rat fed $20 \%$ eggplant supplemented diets. Rats fed with $S$. aetheopicum supplemented diets had the highest PCV $(45.00 \pm 0.87 \%)$ for $10 \%$ treatments while those fed on diets supplemented with S. macrocarpon (oval) had the highest PCV (46.50土1.02\%) for $20 \%$ treatments. No significant difference $(\mathrm{p}>0.05)$ in the PCV level was found among the groups and between the treatments compared to the control.

Table 1: The effect of four Eggplant varieties on the weights of some organ of the experimented rats

\begin{tabular}{lcc}
\hline Group & $\mathbf{1 0 \%}$ treatment & $\mathbf{2 0 \%}$ Treatment \\
\hline Kidney & & \\
Group A & $8.31 \pm 0.17^{\mathrm{a}}$ & $7.79 \pm 0.25^{\mathrm{a}}$ \\
Group B & $7.58 \pm 0.11^{\mathrm{a}}$ & $7.51 \pm 0.33^{\mathrm{a}}$ \\
Group C & $7.58 \pm 0.37^{\mathrm{a}}$ & $7.37 \pm 0.73^{\mathrm{a}}$ \\
Group D & $7.40 \pm 0.30^{\mathrm{a}}$ & $7.82 \pm 0.28^{\mathrm{a}}$ \\
Control & $7.89 \pm 0.41^{\mathrm{a}}$ & $7.89 \pm 0.41^{\mathrm{a}}$ \\
Heart & & \\
Group A & $4.14 \pm 0.33^{\mathrm{a}}$ & $4.45 \pm 0.37^{\mathrm{a}}$ \\
Group B & $3.89 \pm 0.13^{\mathrm{a}}$ & $3.82 \pm 0.24^{\mathrm{a}}$ \\
Group C & $3.91 \pm 0.12^{\mathrm{a}}$ & $3.86 \pm 0.31^{\mathrm{a}}$ \\
Group D & $4.22 \pm 0.34^{\mathrm{a}}$ & $3.97 \pm 0.33^{\mathrm{a}}$ \\
Control & $4.25 \pm 0.20^{\mathrm{a}}$ & $4.25 \pm 0.20^{\mathrm{a}}$ \\
Liver & & \\
Group A & $42.34 \pm 2.22^{\mathrm{a}}$ & $44.64 \pm 3.89^{\mathrm{a}}$ \\
Group B & $40.04 \pm 2.71^{\mathrm{a}}$ & $41.88 \pm 3.94^{\mathrm{a}}$ \\
Group C & $45.37 \pm 2.66^{\mathrm{a}}$ & $42.10 \pm 1.17^{\mathrm{a}}$ \\
Group D & $46.42 \pm 2.37^{\mathrm{a}}$ & $45.48 \pm 2.26^{\mathrm{a}}$ \\
Control & $45.85 \pm 4.69^{\mathrm{a}}$ & $45.85 \pm 4.69^{\mathrm{a}}$ \\
\hline
\end{tabular}

Values are mean \pm standard error of mean (SEM) of triplicate determinations. Mean \pm SEM followed by different letter on a column are significantly different $(\mathrm{p}<0.05)$. 


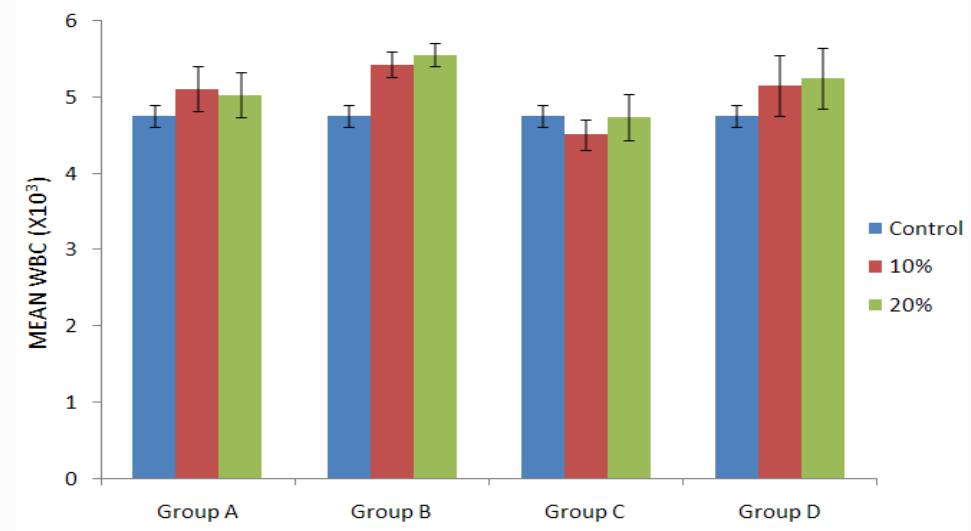

Figure 1: Mean white blood cell count $\left(x_{10} / \mu \mathrm{L}\right)$ of rats fed diet supplemented with $10 \%$ and $20 \%$ of $S$. melongena varieties

Group A - Rats fed with Solanum macrocarpon (round) supplemented diet, Group B - Rats fed with $S$. aetheopicum supplemented diet, Group C - Rats fed with S. macrocarpon (oval) supplemented diet, Group D - Rats fed with $S$. gilo supplemented diet

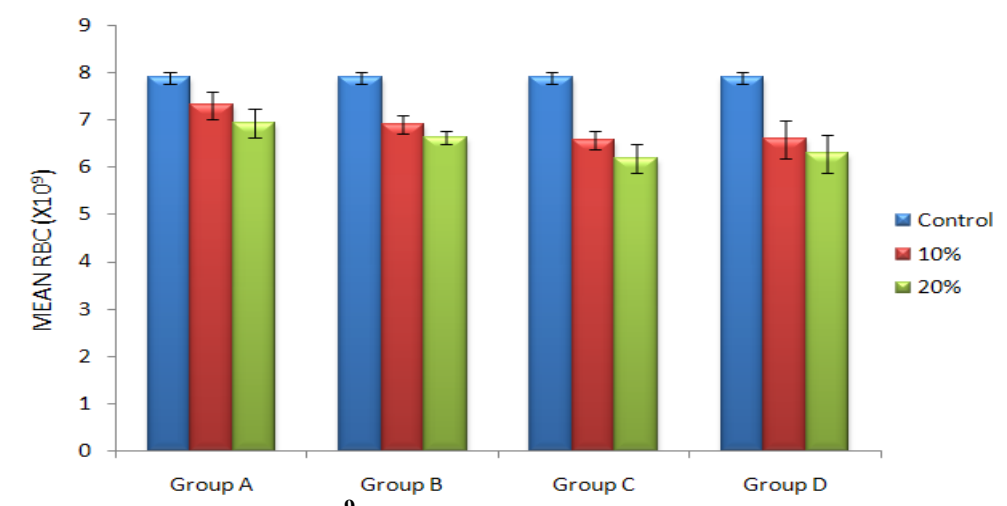

Figure 2: Mean Red blood cell count $(\times 10 \% / \mu \mathrm{L})$ of rats placed on diet supplemented with $10 \%$ and $20 \%$ of S. melongena varieties

Group A - Rats fed with S. macrocarpon (round) supplemented diet, Group B - Rats fed with S. aetheopicum supplemented diet, Group C - Rats fed with S. macrocarpon (oval) supplemented diet, Group D - Rats fed with $S$. gilo supplemented diet

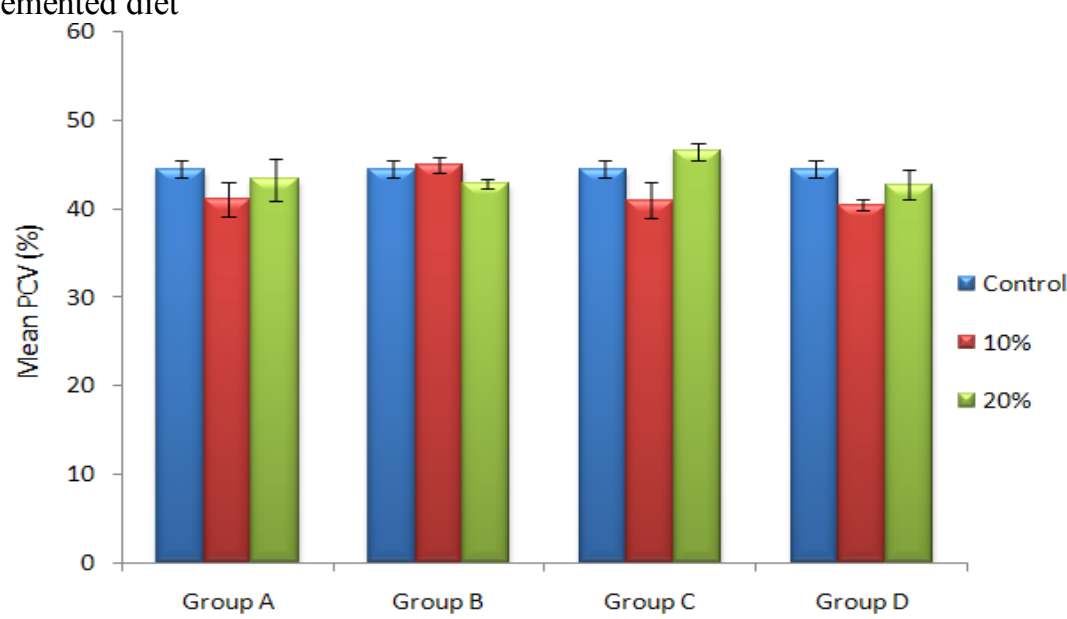

Figure 3: Mean Packed cell volume (\%) of rats placed on diets supplemented with $10 \%$ and $20 \%$ of the $S$. melongena varieties

Group A - Rats fed with Solanum macrocarpon (round) supplemented diet, Group B - Rats fed with $S$. aetheopicum supplemented diet, Group C - Rats fed with S. macrocarpon (oval) supplemented diet, Group D - Rats fed with $S$. gilo supplemented diet 


\section{Discussion}

Organ-body weight ratio has been described by Yakubu et al., 2007 as a marker of cell constriction and inflammation. The non significant $(\mathrm{p}>0.05)$ change in the liver, kidney and heart weight to body weight ratio compared to the control group shows that the various eggplant varieties had no effect on the organs. Eggplant fruits have been reported to contain high amounts of alkaloids (Ossamulu et al., 2014). Although this was not in agreement with the work of Friedman et al., (1995) who reported that consumption of solasodine a glycolalkaloid could induce significant liver enlargement. Many diseases can also affect the size of organs, ranging from infective conditions, inflammations to cancerous or malignant disorders (Joshi et al., 2004). Previous reports on different eggplant varieties have shown that they have considerable high reserves of flavonoids and phenols which possess anti-inflammatory and anticancer properties (Gul et al., 2010; Madiha et al., 2011) thereby curbing any organ inflammation or enlargement.

The significant $(\mathrm{p}<0.05)$ decrease observed in red blood cell agrees with the work of Alhasssan et al., (2012) who reported a significant decrease in the red blood cell count of rats administered $400 \mathrm{mg} / \mathrm{kgbw}$ of $S$. melongena extract. Saponins which is an abundant bioactive compound in eggplant as previously reported in the study of Ossamulu et al., (2014) may cause heamolysis of red blood cells (Kar, 2007). Eggplants have been reported to contain high amount of dietary fiber which have the ability to bind cations (López and Martos 2004 ) such as iron. This may interfere with iron absorption therefore debilitate its bioavailability (Reinhold et al., 1981) as such causing a decrease in red blood cells.

White blood cells (leucocytes) are important component of the immune (host defence) system that are involved in protecting the body against infectious diseases caused by bacteria, fungi, viruses and invading parasites (Stock and Hoffman, 2000). The significant increase in white blood cell count as seen in this study agrees with the work of Alhassan, Mabrouk, Okpe, Salawu and Omotoso, (2012) that investigated the effects of Solanum melongena on blood system of Albino rats and reported an increase in the white blood cell count. Saba, Olayinka and Ofuegbe, (2009) and Lowenthal, Connick, McWater and York, (1994) similarly reported that eggplant may be involved in cellular immunity. Changes in white blood cell count may be due to response to various stimuli which may include variations in hormonal levels, stress, shock, infection, drug, allergic reactions and inflammations. Eggplants have been reported to contain alkaloids (Ossamulu et al., 2014), phytosterol and certain pigment that have been suggested to cause occasional allergies (Patnaik, 1993). As allergic reactions ensue, white blood cells may be mobilized as a result increases their concentration.

The insignificant change $(p>0.05)$ in the PCV level observed among the groups and between the treatments may indicates that the $S$. melongena varieties had no effect on the volume of total cells to plasma volume. The significant increase in white blood cell may have compensated for the significant decrease in red blood cell resulting in little or no change in packed cell volume (PCV) levels.

\section{Conclusion}

This study has shown that the eggplant cultivars had no effect on the kidney, liver and heart weight of the experimental rats. The eggplant varieties except $S$. macrocarpon (oval) caused a significant increase in the white blood cell count of rats placed on it. A significant decrease in red blood cell count was also observed in all the experimental groups although there was no significant change in the packed cell volume.

\section{Acknowledgements}

This research was financed by the management of Liberty Works ltd. Headed by Mr. Heslope N. Imedegwu. Technological expertise was available through Mallam Dauda, Mallam Sani, Mr Prince Ossai and Mallam Shuaibu of the laboratory unit, Biochemistry department, Federal University of Technology Minna, Niger State Nigeria.

\section{References}

[1]. Alhassan, A., Mabrouk, M.A., Okpe, E.A., Salawu, E.O., and Omotoso, O.D. (2012). Effects of Aqueous Extract of Solanum melongena on Blood System of Wistar Rats. World Journal of Life Science and Medical Research, 2(5), 159-164.

[2]. Black, R. (2003). Micronutrient deficiency - an underlying cause of morbidity and mortality. Bulletin of World Health Organisation. 81(2), 79-82.

[3]. Block, G., Patterson, B., Subar, A. 1992. Fruit, vegetables, and cancer prevention: a review of the epidemiological evidence. Nutr Cancerb, 18:1-29.

[4]. Canadian Council on the Care and Use of Laboratory Animals in Biomedical Research (1984). Guide to the Care and Use of Experimental Animals, Vol. 2.

[5]. Doganlar, S., Frary, A., Daunay, M.C., Lester, R.N., and Tanksley S.D. (2002). A comparative genetic linkage map of Solanum melongena (Solanum melongena) and its implications for genome evolution in the solanaceae. Genetics, 161, 1697-1711.

[6]. Ekesa, B.N., Walingo, M., and Abukutsa-Onyango, M.O. (2009). Accessibility to and composition of indigenous vegetables and fruits by rural households in mutungu division, western Kenya. African Food, Agriculture, Nutrition and Development, 9(8), 17251738 .

[7]. Friedman, M., Henika, P.R., and Mackey, B.E. (1995). Feeding of potato, tomato and Solanum melongena alkaloids affects food consumption and body and liver weights in mice. Nutrition, Pharmacology and Toxicology, 989-999. 
[8]. Gul, S., Ahmed, S., Gul, H., \& Kaneez, F. (2010). Investigating the Protective Effect of Solanum melongena. Asian Journal of Health, 1, 276-294.

[9]. Horna, J.D., and Gruere, G. (2006). Marketing Underutilized Crops for Biodiversity; The case of the African Garden egg (Solanum athiopicum) in Ghana. 8th International BioECON Conference, 29-30 August 2006. Kings College Cambridge London

[10]. Ibrahim, F. (2011). Fruity response efficacy and fruit consumption among a group of civil servants of Oyo State, Nigeria. American Journal of Clinical Nutrition, 1(1), 44-48.

[11]. Joshi, R., Singh, A., Jajoo, N., Pai, M., and Kalantri, S.P. (2004). Accuracy and reliability of palpation and percussion for detecting hepatomegaly: a rural hospital based study. Indian Journal of Gastroenterology, 23, 171-174.

[12]. Kar, A. (2007). Pharmaocgnosy and Pharmacobiotechnology (Revised-Expanded Second Edition).

[13]. López, M.A.A., and Marto, F.C. (2004). Iron availability: An updated review. International Journal of food Science Nutrition, 55(8), 597-606.

[14]. Lowenthal, J.W., Connick, T., McWater, P.G., and York, J.J. (1994). Development of T cell immune responsiveness in the chicken. Immunology and Cell Biology, 72,115-122.

[15]. Madiha, M.A., Seham, S.K., Magda, S.M.,Badawy, I.H., El-Shobaki, F.A. (2011).Health evaluation of High Nutritional Meals for school children. Agriculture and Biology Journal of North America, 2 (5), 832-839.

[16]. Olson, H., Betton, G., Robinson, D., Thomas, K., Monro, A., Kolaja, G., ... Heller, A. (2000). Concordance of the toxicity of pharmaceuticals in humans and in animals. Toxicology and Pharmacology, 32, 56-67

[17]. Ossamulu, I.F., H.O Akanya,. A.A. Jigam and E.C. Egwim,. Nutrient and phytochemical constituents of four eggplant varieties. Elixir Food Science, 73 (2014), 2014, 26424-26428.

[18]. Patnaik, N. (1993).Garden of Life: An introduction to the healing plants of India. New Delhi: Aquarian, an imprint of HarperCollins Publishers. pp. 106-107.

[19]. Reinhold, J.G., Garcia, L.J.S., and Garzon, P.M.D. (1981). Binding of iron by fiber of wheat and maize. American Journal of Clinical Nutrition, 34, 1384-1391.

[20]. Saba, A.B., Olayinka, A.O., and Ofuegbe, S.O. (2009). Evaluation of haematological and serum electrolyte changes in Wistar rats administered with ethanolic extract of whole fruit of Lagenaria breviflora Robert. Journal of Medicinal Plants Research, 3(10), 758762 .

[21]. Saliu, J.A., Elekofehinti, O.O., Komolafe, K., \& Oboh, G. (2012). Effects of some green leafy vegetables on the haematological parameters of diabetic rats. Journal of Natural Products and Plant Resources, 2 (4), 482-485.

[22]. Sokal, R.R., and Rohlf F.J. (1969). The principles and practice of statistics in biological research. San Francisco: Freeman and Co., $469-484$.

[23]. Stock, W., and Hoffman, R. (2000). White blood cells 1: non-malignant disorders. Lancet 355, $1351-1357$.

[24]. Stover, E. W., Aradhya, M. K., Crisosto, C. and Ferguson, L. 2007. The fig: Over-view of an ancient fruit. Hort Science, 42 : 1083 1087.

[25]. Vinson, J.A., Ligia, Z., Pratima, B., Samman, N. and Proch, J. 2005. Dried fruits: Ecellent in vitro and in vivo antioxidants. J. Amer. Coll. Nutr., 24(1): 44-50.

[26]. Yakubu, M.T., Akanji, M.A and Oladiji, A.T. (2007). Effect of Chronic Administration of Aqueous Extract of Fadogia agrestis Stem on Male Rat. Medicinal Plants Research Laboratory, 1(1), 49-56.

[27]. Zuckerman, K. (2007). Approach to the anaemias. In: Goldman L, Ausiello D. (Editors). Cecil Medicine, 23rd edition. Philadelphia, Pa: Saunders Elsevier: chap 162. 